\title{
PCNA wt Allele
}

National Cancer Institute

\section{Source}

National Cancer Institute. PCNA wt Allele. NCI Thesaurus. Code C49534.

Human PCNA wild-type allele is located within 20pter-p12 and is approximately $30 \mathrm{~kb}$ in length. This allele, which encodes proliferating cell nuclear antigen immunoprotein, is involved in the regulation of DNA processivity activities. 